\title{
The Influence of The Biopsy Procedure on The Quality of a Three-Dimensional Reconstructed Artificial Tissue
}

\author{
Biyopsi Yönteminin Geliştirilen Üç Boyutlu Yapay Dokunun \\ Kalitesine Olan Etkisi
}

Research Article

Beste Kınıkoğlu

Department of Medical Biology, School of Medicine, Acıbadem University, Istanbul, Turkey and Hospices Civils de Lyon, Lyon, France.

\section{A B S TR ACT}

\begin{abstract}
The aim of the present study was to investigate the impact of the initial biopsy harvest procedure on the quality of the final reconstructed tissue. For this purpose, two full-thickness human oral mucosa models were reconstructed by tissue engineering from epithelial cells and fibroblasts obtained via punch or laser biopsy procedures and they were analyzed by using histology, immunohistochemistry, and transmission electron microscopy. The results showed that the oral mucosa model reconstructed by using punch biopsy mimicked very closely the native oral mucosa both morphologically and histologically; on the other hand, laser biopsy resulted in an artificial oral mucosa with less desirable properties.
\end{abstract}

Key Words

Tissue engineering, oral mucosa, biomaterials, biopsy method.

\section{Ö z}

u çalışmanın amacı, biyopsi yönteminin oluşturulan yapay dokunun kalitesine olan etkisini incelemektir. Bu doğrultuda, lazer veya punch biyopsi yöntemleri kullanılarak elde edilen epitel ve fibroblast hücreleri ile iki tam kalınlıkta, üç boyutlu, yapay ağız mukozası modeli oluşturulmuştur. Sonrasında, bu modeller histoloji, immünohistokimya ve geçirimli elektron mikroskopisi kullanılarak incelenmişlerdir. Elde edilen sonuçlar, punch biyopsisi kullanılarak geliştirilen yapay ağız mukozasının morfolojik ve histolojik olarak doğalına çok benzediğini, fakat lazer biyopsisi kullanılarak elde edilen yapay mukozanın, doğal mukozadan farklı olarak istenmeyen bazı özellikler taşıdığını göstermiştir.

\section{Anahtar Kelimeler}

Doku mühendisliği, ağız mukozası, biyomalzemeler, biyopsi yöntemi.

Article History: Received: Mar 9, 2017; Revised: Jul 25, 2017; Accepted: Oct 2, 2017; Available Online: Dec 25, 2017.

DOI: $10.15671 /$ HJBC.2018.181

Correspondence to: B. Kinikoglu, Department of Medical Biology, School of Medicine, Acibadem University, Istanbul, Turkey. 


\section{INTRODUCTION}

Tror issue engineering aims to produce substitutes for the injured or diseased tissues by using a combination of cells and neosynthesized or reconstituted extracellular matrix (ECM) [1]. The resulting tissue-engineered product is required to mimic the native tissue as much as possible in terms of morphology, histology and functionality. In order to achieve this, it is crucial to identify and control the parameters such as scaffold porosity, strength, shape, composition, cell type, culture conditions and many more that can affect the characteristics of the reconstructed tissue. Adjusting these parameters can enhance the quality of the engineered tissue.

Despite advances in tissue engineering and several studies on the optimization of the quality of reconstructed tissues, little attention has been paid so far to the effect of the initial biopsy harvest procedure on the quality of the final tissue-engineered product. To the best of our knowledge, the present study is the first to examine this relationship.

The general approach in tissue engineering is to harvest cells from the tissue, proliferate and seed them on an appropriate biodegradable scaffold before implantation into the patient [2]. The source of donor tissue can be heterologous (such as bovine), allogeneic (same species, different individual), or autologous. The most preferred cells to use are autologous cells, where a biopsy of tissue is obtained from the host, the cells are dissociated and expanded in culture, and the expanded cells are implanted into the same host. The use of autologous cells avoids rejection, and thus the deleterious side effects of immunosuppressive medications can be avoided [3]. Two procedures widely used for the harvest of oral mucosa and skin biopsies to obtain autologous cells for tissue engineering applications are punch biopsy and laser excision. In this report, cells isolated from human oral mucosa biopsies removed from the cheek region of the buccal cavity by either punch biopsy or laser excision were used to reconstruct full thickness oral mucosa equivalents. The qualities of these oral mucosa equivalents were compared in terms of their morphology and histology.

Tissue engineering of oral mucosa aims to use a human oral mucosal equivalent for treatment and closure of oral surgical wounds, as well as for studies of the biology and pathology of oral mucosa, and as a model alternative to animals for safety testing of oral care products in an in vitro system [4]. Accordingly, the development of an oral mucosal equivalent would offer the oral and maxillofacial surgeon a material to assist in reconstruction of the oral cavity, predesigned and constructed according to the needs of the patient and surgeon [5]. Several studies have focused on the development of tissueengineered oral mucosa models from primary cell cultures [6-14] but the influence of the biopsy harvest method, for the isolation of these cells, remains to be elucidated.

The aim of the present study was to investigate the impact of the initial biopsy harvest method on the quality of the reconstructed three-dimensional human oral mucosa by using histology, immunohistochemistry, and transmission electron microscopy.

\section{MATERIALS and METHODS}

\section{Origin, Isolation, and Culture of Human Epithelial Cells and Fibroblasts}

The research was conducted according to the principles expressed in the Declaration of Helsinki. Epithelial cells and fibroblasts were isolated from human oral mucosal biopsies obtained with informed consent from patients undergoing oral surgery, which was approved by the institutional ethics committee. After sterilization of the oral cavity and local anesthesia, a $3 \times 3-\mathrm{mm}$ oral mucosa biopsy was excised from the cheek by either punch biopsy or laser excision. The specimens were first measured, and then cut into small pieces in order to increase the efficacy of the enzymes used. The separation of the epithelium from the lamina propria was performed with dispase (GIBCO), $10 \mathrm{mg} / \mathrm{mL}$ for $3 \mathrm{~h}$ at $4^{\circ} \mathrm{C}$. After separation, epithelium was treated with trypsin 0.5 $\mathrm{g} / \mathrm{L}$-EDTA $0.2 \mathrm{~g} / \mathrm{L}$ for $20 \mathrm{~min}$ to extract the cells, which were collected every $10 \mathrm{~min}$. Epithelial cells were grown at 8000-10 000 cells $/ \mathrm{cm}^{2}$ on a feeder layer of irradiated human fibroblasts in a specially designed medium as follows: DMEM-Ham- F12 2.78/1 (Sigma), 10\% fetal calf serum (Hyclone), $0.4 \mathrm{mg} / \mathrm{mL}$ hydrocortisone (Upjohn), $0.12 \mathrm{UI} / \mathrm{mL}$ insulin (Umuline, Lilly), $0.033 \mathrm{mg} / \mathrm{mL}$ selenium (Laboratoire Aguettant), $0.4 \mathrm{mg} / \mathrm{mL}$ isoprenaline 
hydrochloride (Isuprel, Sterling Winthrop), $2 \times 10^{-9}$ $\mathrm{M}$ tri iodo thyronine (Sigma), $10 \mathrm{ng} / \mathrm{mL}$ epidermal growth factor (Austral Biologicals), and antibiotics. Isolation of fibroblasts was performed with collagenase A (Roche Diagnostics), $0.1 \mathrm{U} / \mathrm{mL}$ for $20 \mathrm{~min}$ at $37^{\circ} \mathrm{C}$ with continuous stirring. The digest was purified through a $70 \mathrm{~mm}$ cell strainer (BD Biosciences). This procedure was repeated 6 times, and then the digest was immediately placed in monolayer culture. Fibroblasts were seeded at a density of 10,000 cells $/ \mathrm{cm}^{2}$ and cultured in fibroblast medium composed of DMEM, 10\% newborn calf serum (NCS), and antibiotics. All cells were seeded on the foams at passage 3 .

\section{Scaffold Preparation}

Collagen-GAG-chitosan substrates were prepared as previously described [15]. Briefly, types I and III bovine collagens, chitosan ( $95 \%$ deacylated) and chondroitin 4- 6 sulfates (LPI, Lyon, France) were dissolved in water and mixed. After mixing, the gel, which contained $72 \%$ collagen, $20 \%$ chitosan and $8 \%$ GAG, was poured into Snapwell inserts (Costar) and frozen overnight at $-70^{\circ} \mathrm{C}$. The frozen plates were then lyophilized, submerged in $70 \%$ ethanol for $24 \mathrm{~h}$, rinsed and equilibrated in $5 \mathrm{~mL}$ of DMEM, and incubated at $37^{\circ} \mathrm{C}$ with $5 \% \mathrm{CO}_{2}$ for a minimum of $24 \mathrm{~h}$.

\section{Preparation of Epithelialized, Full-Thickness Oral Mucosa Equivalents}

Lamina propria equivalents consisted of collagen-glycosaminoglycan-chitosan (CGC) foams in which human oral mucosal fibroblasts were cultured. Briefly, lamina propria equivalents were prepared by adding a suspension of $2.5 \times 10^{5} / \mathrm{cm}^{2}$ on top of the $4 \mathrm{~cm}^{2}$ CGC foam. Equivalents were then cultured for 21 days in a medium composed of DMEM, $10 \%$ fetal calf serum, $10 \mathrm{ng} / \mathrm{mL}$ epidermal growth factor, $50 \mathrm{mg} / \mathrm{mL}$ ascorbic acid (Bayer). Culture medium was changed daily until the seeding of epithelial cells. Human epithelial cells were plated on lamina propria equivalents at a concentration of $2.5 \times 10^{5} / \mathrm{cm}^{2}$. Epithelialized oral mucosal substitutes were cultured in epithelial cell medium supplemented with $50 \mathrm{mg} / \mathrm{mL}$ ascorbic acid (Bayer) under submerged conditions for 7 days. They were then elevated at the air-liquid interface for the remaining 14 days in another medium with DMEM-Ham-F12 2.2/1 (Sigma), 8 mg/
$\mathrm{mL}$ bovine serum albumin, $0.4 \mathrm{mg} / \mathrm{mL}$ hydrocortisone (Upjohn), $0.12 \mathrm{UI} / \mathrm{mL}$ insulin (Umuline, Lilly), $50 \mathrm{mg} / \mathrm{mL}$ ascorbic acid (Bayer), and antibiotics.

\section{Histology}

Tissue equivalents were fixed in $4 \%$ formaldehyde solution and embedded in paraffin. Sections, 5 $\mathrm{mm}$ thick, were cut and stained using hematoxylin-phloxin-saffron (HPS).

\section{Immunohistochemistry}

The primary antibodies used in this study to label the oral mucosal equivalents were anti-cytokeratin 13 (K13, Chemicon), anti-laminin 5 (Chemicon) and anti-Ki67 (Novocastra). For the detection of K13 and laminin 5, tissue equivalents were embedded in OCT and frozen at $-20^{\circ} \mathrm{C}$. Then, sections of $6 \mathrm{~mm}$ thickness were fixed in acetone for 10 min at $-20^{\circ} \mathrm{C}$ and blocked in phosphate buffered saline containing $4 \%$ bovine serum albumin and $5 \%$ normal goat serum. All primary antibodies were incubated for $90 \mathrm{~min}$ at room temperature. The secondary antibody was AlexaFluor 488 IgG (Invitrogen). For Ki67 antigen detection, same procedure was applied on formalin fixed paraffin embedded tissue with high temperature antigen retrieval and overnight incubation of the primary antibody. Propidium iodide stain was used to stain the cell nuclei. Specimens were analyzed with a Nikon Eclipse Fluorescence Microscope.

\section{Transmission Electron Microscopy}

Tissue equivalents were fixed with $2 \%$ glutaraldehyde-0.1 M NaCacodylate/ $\mathrm{HCl}, \mathrm{pH} 7.4$ for $2 \mathrm{~h}$ and postfixed with $1 \%$ osmium tetroxide- $0.15 \mathrm{M}$ $\mathrm{NaCacodylate} / \mathrm{HCl}, \mathrm{pH} 7.4$ for $1 \mathrm{~h}$. After dehydration in a growing gradient of ethanol, the samples were embedded in Epon $A+B$ and finally polymerized at $60^{\circ} \mathrm{C}$ for $48 \mathrm{~h}$. The blocks were cut using an ultramicrotome and sections of $60-80 \mathrm{~nm}$ thickness were contrasted with uranyl acetate and lead citrate. Observations were performed with a JEM JEOL 1400 transmission electron microscope and images were recorded using an Orius Gatan camera.

\section{RESULTS and DISCUSSION}

Histological analysis of the tissue-engineered oral mucosa models from cells obtained via punch 
biopsy (model 1) or laser excision (model 2) showed the significant effect of the biopsy removal method on the quality of the reconstructed tissue (Figure 1). In both models, oral fibroblasts seeded into the collagen-GAG-chitosan (CGC) scaffolds were able to proliferate, migrate within the thickness of the substrate, and synthesize new extracellular matrix, giving rise to a reconstructed lamina propria. However, more fibroblasts were detected in model 1 (Figure $1 \mathrm{~A}$ ) compared to model 2 (Figure 1B), and as a result the pores of the CGC scaffold were filled with the newly synthesized extracellular matrix in the former model by the fibroblasts. In model 2, voids were detected in the reconstructed lamina propria (Figure 1B). At the top of the reconstructed lamina propria, oral epithelial cells proliferated during 7 days of culture under submerged conditions and 14 days of culture at an air-liquid interface, forming a nonkeratinized epithelium and giving rise to a full-thickness reconstructed oral mucosa. However, the quality of the reconstructed epithelia significantly differed between two models. In model 1, the epithelium was multilayered (7-8 layers thick) (Figure 1A) as in native oral mucosa, but in model 2 it consisted of a single layer (Figure 1B). The reconstructed epithelium of model 1 was firmly anchored to the underlying reconstructed lamina propria by a continuous and well-organized basement memb- rane (Figure $1 \mathrm{~A}$ ). However, in model 2, it was loosely attached to the reconstructed lamina propria and even detached in some parts (Figure 1B). A well-organized basal epithelial cell layer could not be found, unlike in model 1 (Figure 1B). In both models, the epithelial cells were seen to retain their nuclei and stratum corneum was absent as in native nonkeratinized oral mucosa. These results showed that the biopsy harvest procedure significantly affects the quality of the reconstructed oral mucosa, in terms of the thickness of the epithelium, the structure and organization of the basement membrane region and epithelial basal cell layer, and the amount of newly synthesized extracellular matrix by the fibroblasts. It should be noted that the oral epithelial cells seemed to be more affected by the biopsy method compared to oral fibroblasts. This could be due to the fact that they might be more prone to the adverse effect of laser, such as high temperature, residing at the outermost layer of the tissue; fibroblasts might be better protected from environmental factors residing in the lamina propria part of the tissue, under the protective epithelium and embedded in the extracellular matrix.

Keratin 13 (K13), marker of nonkeratinized oral epithelia, was strongly expressed in both models (Figure 2A and B; green), as was laminin 5, classical
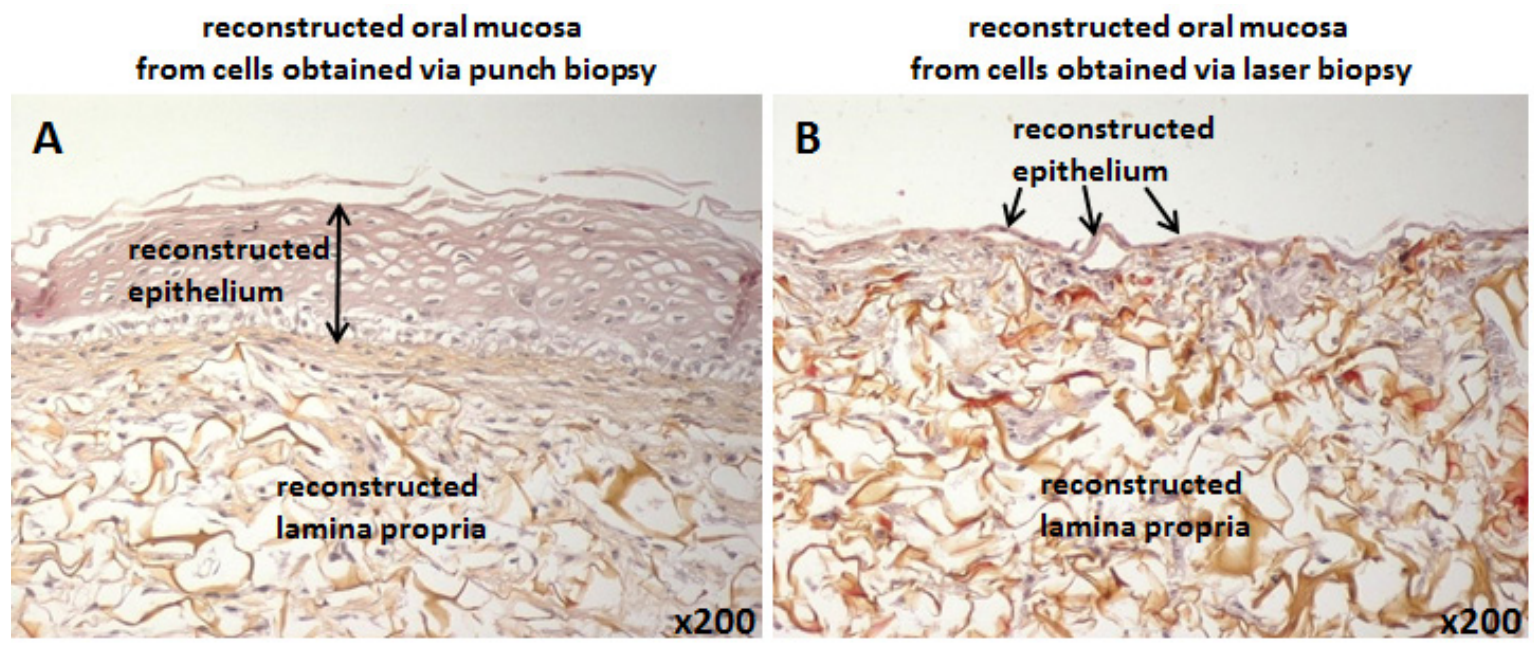

Figure 1. Histological analysis of the tissue-engineered oral mucosa models reconstructed from cells obtained via punch biopsy (model 1, A), and via laser excision (model 2, B). Cell nuclei were stained in blue by hematoxylin, cytoplasm in pink by phloxine and extracellular matrix of connective tissue in orange/yellow by saffron. Oral fibroblasts seeded into the collagen-GAG-chitosan foams migrated, proliferated and populated the foams, though in lesser extend in model 2 compared to model 1. The pores were filled with newly synthesized extracellular matrix; but some voids could still be seen in model 2. Oral epithelial cells formed nonkeratinized epithelia on the surface of both models and were seen to retain their nuclei. Epithelium of model 1 was multilayered (7-8 layers) with a well-organized and continuous basement region; on the other hand, epithelium of model 2 was single layered with a disorganized basement region. 
marker of basement membranes (Figures 2C and D; green). Basement membrane is an important feature a reconstructed oral mucosa should possess, it is the attachment zone necessary to withstand sheer stress in oral mucosa [5], and also has an important role in wound healing and disease [16]. The presence of a continuous and well-organized basement membrane has been shown to be the result of interactions between fibroblasts and epithelial cells [17].
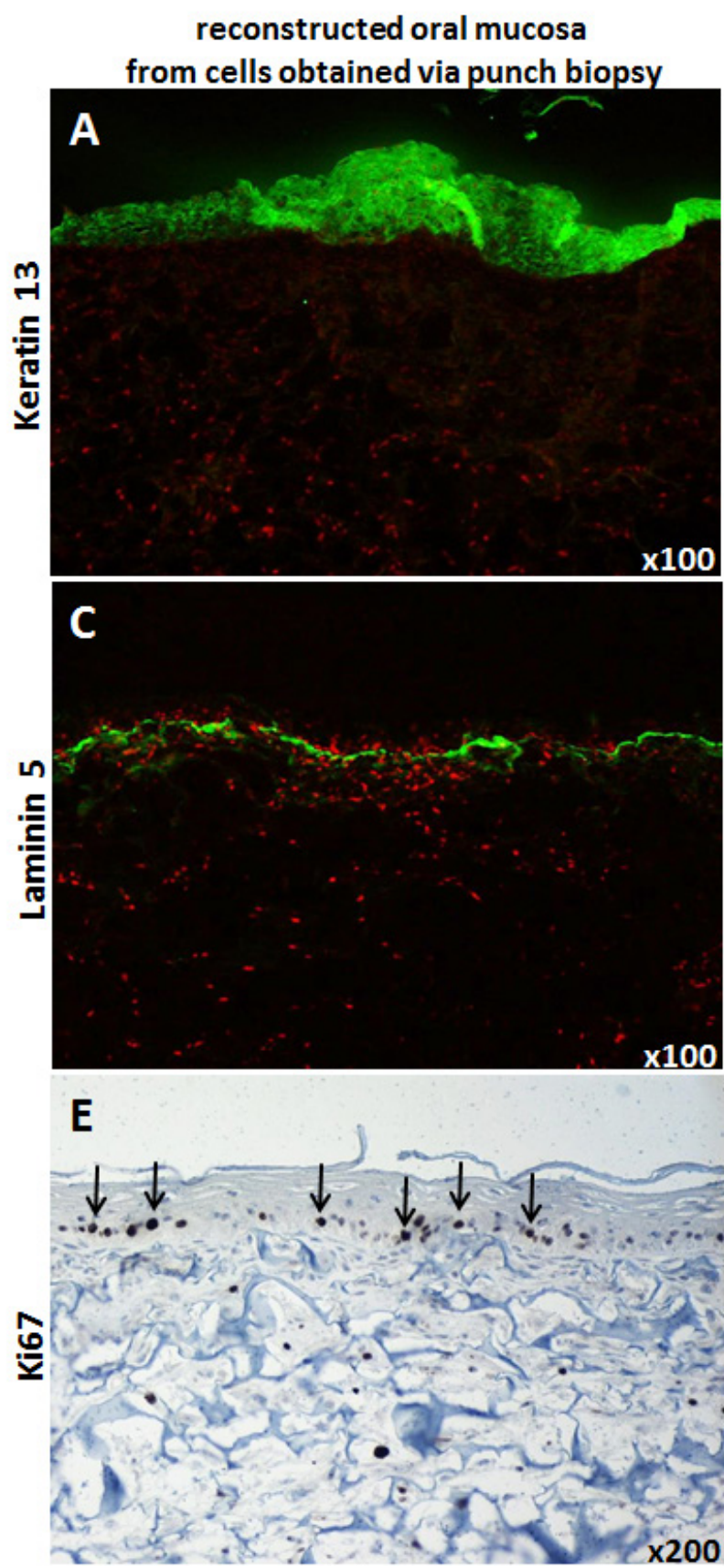

Figure 2. Immunohistochemical labeling of keratin 13 (K13), marker of nonkeratinized epithelium; basement membrane protein laminin 5; and proliferating cell antigen $\mathrm{Ki} 67$ in the oral mucosa equivalents reconstructed from cells obtained via punch biopsy (model 1; A,C,E), and via laser excision (model 2; B,D,F). For K13 and laminin 5, immunolabeling is shown in green, cell nuclei are shown in red. For Ki67, immunolabeling is shown in black and arrows.
Here, our results show that both models permitted contact between the two types of cells, resulting in a continuous basement membrane expressing laminin 5. Ki67, a marker of proliferative cells, was detected in the basal epithelial cells of the model 1, as in native oral mucosa and skin, indicating that this model of oral mucosa was capable of self-renewal (Figure 2E, arrows). However, it was absent in model 2 (Figure 2F). Epithelial cells obtained via laser

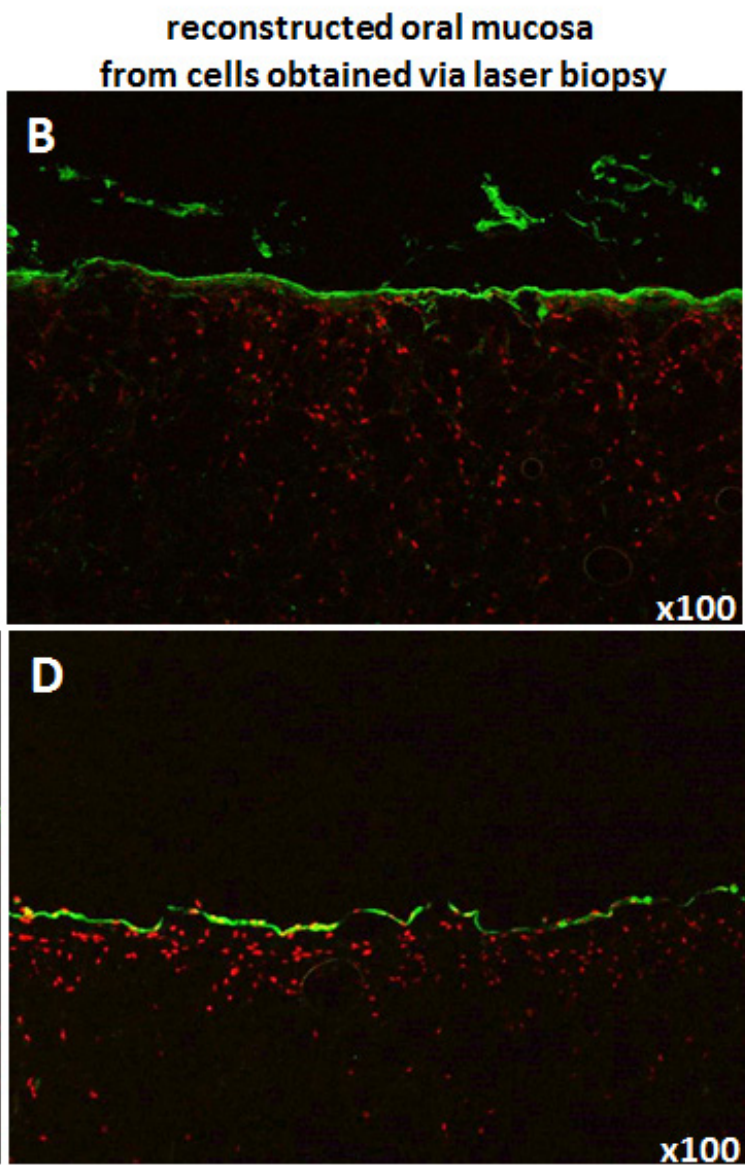

$\mathbf{F}$

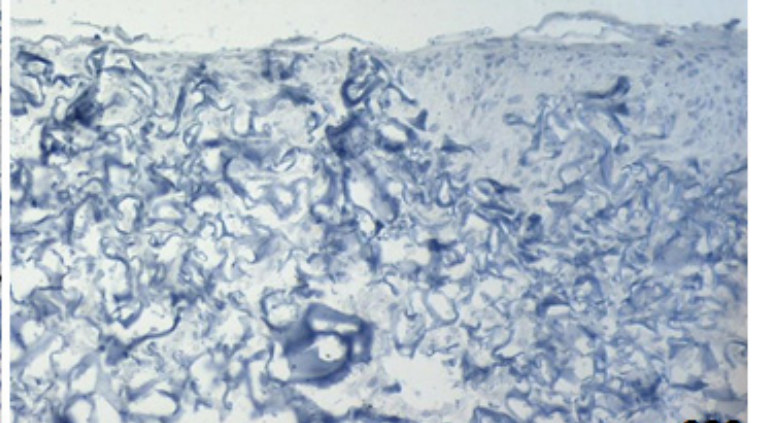
$\times 200$ 
biopsy seem to have lost their proliferative capacity, as also evidenced by the very thin layer of epithelium that they formed (Figure 1B). In both models, Ki67 antigen staining was performed at the end of epithelial formation ( 3 weeks after epithelial cell seeding), to investigate whether even after such a longtime, the cells were still able to proliferate, and if transplanted in vivo, whether the epithelium of the reconstructed tissue would still be able to selfrenew. The results of the present study showed that by using punch biopsy, it was possible to obtain such model with high self-renewal capacity, but with laser biopsy it was not.

Ultrastructure of the reconstructed oral mucosa models was investigated by using transmission electron microscopy (TEM). Overall, both the re- constructed epithelium and lamina propria of the model 1 were much better organized ultrastructurally, compared to model 2 . The epithelium of the model 1 was stratified in several layers (Figure 3A). In the subepithelial layer and in the deep layer of lamina propria of the model 1, high amount of newly synthesized collagen was detectable by TEM, with visible striations at high magnification (Figure 3B). The connective tissue was represented by fibrils of collagen which were either parallel to the oral surface or vertical.

In addition, by using TEM, several desmosomes could be detected at the epithelium level of model 1 (Figure $3 \mathrm{C}$ and $\mathrm{D}$ ), these intercellular junctions are crucial for epithelial adhesion and barrier function in stratifying epithelia [18]. They could not be detec-
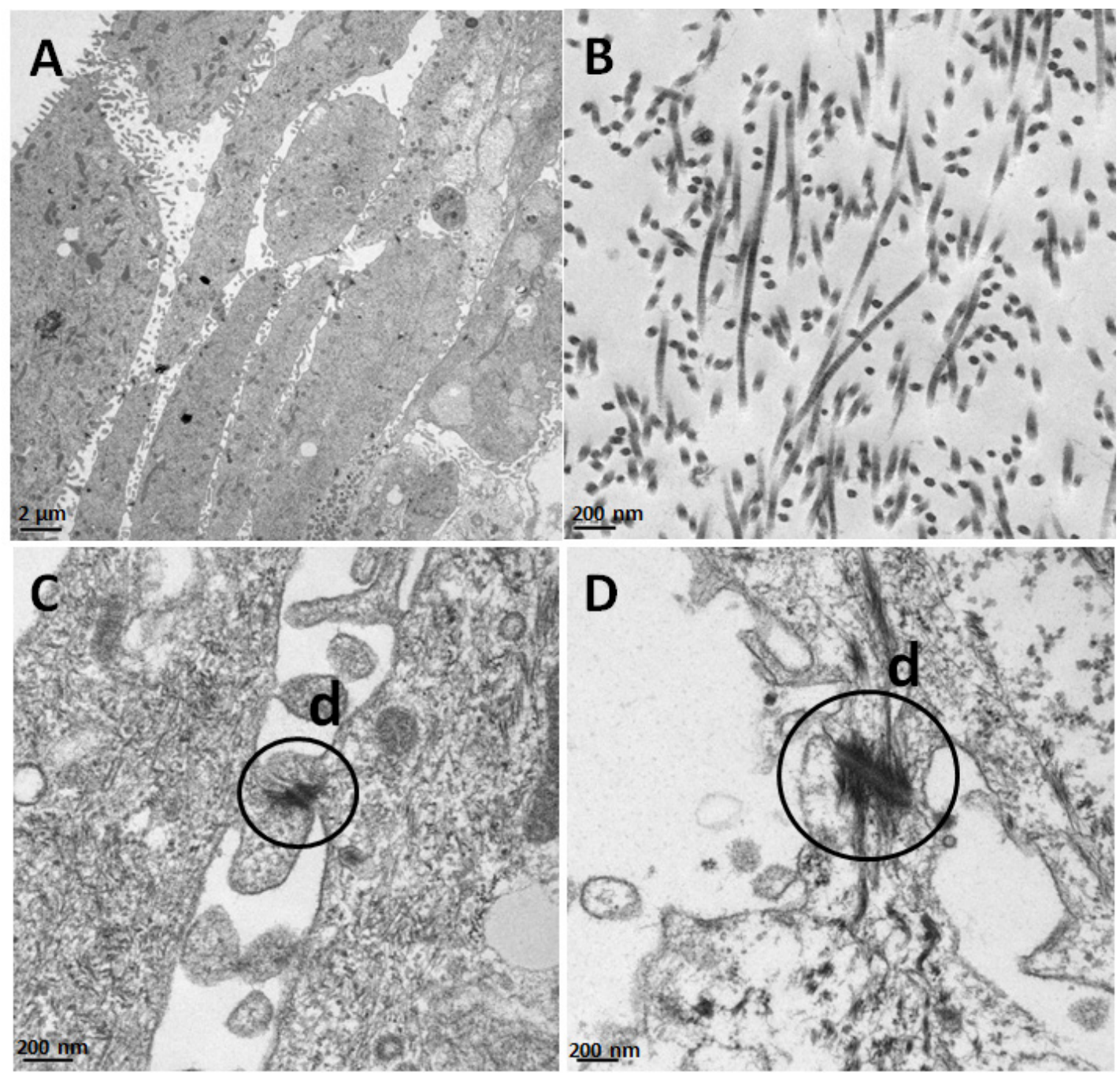

Figure 3. Ultrastructural analysis of the reconstructed full-thickness oral mucosa by transmission electron microscopy. A) different cell layers and their organization in the epithelium of model 1, B) newly synthesized collagen I fibrils parallel or vertical to the surface could be detected in the lamina propria of model $1, C$ ) and D) numerous desmosomes (d) were detected between adjacent oral epithelial cells of model 1 . 
ted in the reconstructed epithelium of model 2.

This study elucidates the impact of the biopsy harvest method on the quality of the final threedimensional, reconstructed oral mucosa. We demonstrated that by using punch biopsy, as the initial tissue harvest method, it was possible to develop a full-thickness human oral mucosa model very similar to native tissue: comprised of a multilayered, thick epithelium, with a continuous and well-organized basement membrane region and proliferating epithelial cells, and an underlying reconstructed lamina propria composed of functional fibroblasts synthesizing new extracellular matrix. On the other hand, laser excision procedure resulted in an oral mucosa equivalent with less desirable properties.

\section{ACKNOWLEDGEMENTS}

The author would like to thank Dr. Carole Burillon and Dr. Pascal Pierrillas for human oral mucosa specimens.

\section{References}

1. R. Langer, J.P. Vacanti, Tissue engineering, Science, 260 (1993) 920-926.

2. B. Kinikoglu, O. Damour, V. Hasirci, Tissue engineering of oral mucosa: a shared concept with skin, J. Artif. Organs, 18 (2015) 8-19.

3. C.J. Koh, A. Atala, Tissue engineering, stem cells, and cloning: opportunities for regenerative medicine, J. Am. Soc. Nephrol., 15 (2004) 1113-1125.

4. B. Kinikoglu, C. Auxenfans, P. Pierrillas, V. Justin, P. Breton, C. Burillon, et al., Reconstruction of a full-thickness collagen-based human oral mucosal equivalent, Biomaterials, 30 (2009) 6418-6425.

5. S.E. Feinberg, T.L. Aghaloo, L.L. Cunningham Jr., Role of tissue engineering in oral and maxillofacial reconstruction: findings of the 2005 AAOMS Research Summit, J. Oral Maxillofac. Surg., 63 (2005) 1418-1425.

6. X. Xiong, Y. Zhao, W. Zhang, W. Xie, S. He, In vitro engineering of a palatal mucosa equivalent with acellular porcine dermal matrix, J. Biomed. Mater. Res. A, 86 (2008) 544-551.

7. W.M. Tra, J.W. van Neck, S.E. Hovius, G.J. van Osch, S. Perez-Amodio, Characterization of a threedimensional mucosal equivalent: similarities and differences with native oral mucosa, Cells Tissues Organs, 195 (2012) 185-196.
8. M. Alaminos, I. Garzon, M.C. Sanchez-Quevedo, G. Moreu, M. Gonzalez-Andrades, A. Fernandez-Montoya, et al., Timecourse study of histological and genetic patterns of differentiation in human engineered oral mucosa, J. Tissue Eng. Regen. Med., 1 (2007) 350-359.

9. K.H. Cho, H.T. Ahn, K.C. Park, J.H. Chung, S.W. Kim, M.W. Sung, et al., Reconstruction of human hardpalate mucosal epithelium on deepidermized dermis, J. Dermatol. Sci., 22 (2000) 117-124.

10. R. Ophof, R.E. van Rheden, J.W. Von den Hoffa, J. Schalkwijk, A.M. Kuijpers-Jagtman, Oral keratinocytes cultured on dermal matrices form a mucosa-like tissue, Biomaterials, 23 (2002) 3741-3748.

11. T. Iida, Y. Takami, R. Yamaguchi, S. Shimazaki, K. Harii, Development of a tissue-engineered human oral mucosa equivalent based on an acellular allogeneic dermal matrix: a preliminary report of clinical application to burn wounds, Scand. J. Plast. Reconstr. Surg. Hand Surg., 39 (2005) 138-146.

12. R.H. Bustos, E. Suesca, D. Millan, J.M. Gonzalez, M.R. Fontanilla, Real-time quantification of proteins secreted by artificial connective tissue made from uni- or multidirectional collagen I scaffolds and oral mucosa fibroblasts, Anal. Chem., 86 (2014) 24212428.

13. I. Pena, L.M. Junquera, A. Meana, E. Garcia, V. Garcia, J.C. De Vicente, In vitro engineering of complete autologous oral mucosa equivalents: characterization of a novel scaffold, J. Periodontal. Res., 45 (2010) 375-380.

14. S. San Martin, M. Alaminos, T.M. Zorn, M.C. SanchezQuevedo, I. Garzon, I.A. Rodriguez, et al., The effects of fibrin and fibrinagarose on the extracellular matrix profile of bioengineered oral mucosa, J. Tissue Eng. Regen. Med., 7 (2013) 10-19.

15. C. Collombel, O. Damour, C. Gagnieu, J. Marichy, F. Poinsignon, Biomaterials with a base of collagen, chitosan and glycosaminoglycans; process for preparing them and their application in human medicine, French patent 8708252, 1987. European patent 884101948,1988 . US patent PCT/FR/8800303, 1989.

16. T.A. Winning, G.C. Townsend, Oral mucosal embryology and histology, Clin. Dermatol., 18 (2000) 499-511.

17. F. Sahuc, K. Nakazawa, F. Berthod, C. Collombel, O. Damour, Mesenchymal-epithelial interactions regulate gene expression of type VII collagen and kalinin in keratinocytes and dermal-epidermal junction formation in a skin equivalent model, Wound Repair Regen., 4 (1996) 93-102.

18. C.M. Niessen, Tight junctions/adherens junctions: basic structure and function, J. Invest. Dermatol., 127 (2007) 2525-2532. 
